\title{
DIE KLEINE HOUSE-APOTHEKE: RECEPTION OF THE AMERICAN, GERMAN AND POLISH GREGORY HOUSE AND VARIED TRANSLATIONS OF THE PRONOUN YOU
}

\author{
ANNA URBAN \\ Adam Mickiewicz University, Poznań \\ aurban@amu.edu.pl
}

\begin{abstract}
Two audiovisual translations of the American hit medical drama, House M.D., German dubbing and Polish voiceover, and the analysis of translation strategies of the pronominal form of address you are the point of departure for choosing the right strategy for translation of the German book written by Michael Reufsteck and Jochen Stöckle Die kleine House-Apotheke. Ein Beipackzettel zur Kultserie which is the first German guide to the hit medical drama, providing unique insight into making of each episode of the first three series. The comparison of the two translation strategies - the German and the Polish one - shows that translation of the pronoun you determined the reception of the main protagonist. The reduced pronominal paradigm in English which does not distinguish between a formal and an informal address pronoun has created two different protagonists.
\end{abstract}

\section{Introduction}

For the last seven years House, M.D. has been one of the most popular and captivating shows on television around the world. Every week the misanthropic genius doctor named Gregory House and his team of diagnosticians are confronted with medical mysteries. Due to the brilliantly portrayed main character the Emmy Award winning TV drama has been offering viewers all around the globe an entertaining mixture of drama and humour.

The incentive for the present paper was a German book by Michael Reufsteck and Jochen Stöckle Die kleine House-Apotheke. Ein Beipackzettel zur Kultserie which is after the English TV guides (Barnett 2010 and Jackman \& Laurie 2010) the first German guide to the hit medical drama. Providing unique insight into the show, the book also offers a detailed look at the dubbed House M.D. episode after episode of the first three series.

It must be mentioned that Die kleine House-Apotheke, a book written in German about the American TV series, based on the German dubbing and riddled with quotations from the show, was to be translated from German into Polish. As the authors are German journalists, the text is written in German, but the hundreds of quotations are translations and excerpts from the TV show, as well as all key-words, diagnoses and whole dialogs, therefore the translation must be taken up cautiously in a constant balance on the line between the three mentioned languages: German, English and Polish. 
The illustration of numerous problematic issues that the translator must tackle in the above mentioned triad will be incorporated in the analysis of forms of address.

The first observation is that the translation task will not only involve the translation of the book itself. The translator must understand that in this case the target book would be an outcome of the German book, the German dubbing, the American drama and its Polish audiovisual translation (AVT in short), being not dubbing, but voiceover.

Under dubbing Dries (1995:9 qtd. in Shuttleworth \& Cowie 1997:45) understands a process in which "the foreign dialogue is adjusted to the mouth movements of the actor in the film" giving the impression the that actor is actually speaking the target language, According to Díaz Cintaz and Orero (2005:473), voice-over is "a technique in which a voice offering a translation in a given target language (TL) is heard simultaneously on top of the source language (SL) voice. As far as the soundtrack of the original program is concerned, the volume is reduced to a low level that can still be heard in the background whilst the translation is being read".

Probably the latter, that is the Polish AVT of the medical drama, is to be the key to a successful translation of the book in question. Most presumably the target reader is not a novice to the subject, but the viewer of the former six television series. Both the German book and its Polish counterpart are addressed to the fan of House M.D., that is, a viewer who knows the unconventional and misanthropic medical genius heading a team of diagnosticians at the fictional Princeton-Plainsboro Teaching Hospital (PPTH) in New Jersey.

Having that in mind, what the viewer is expecting to find in the book is a detailed look at the making of each episode with his favourite character. The fact that the source text is written in German is probably of no relevance to the reader.

\section{Forms of address in translation}

Forms of address is a broad umbrella term which comprises two major types: 1) vocatives (Levinson 1983; Huddlestone \& Pullum 2002) and 2) verbal and pronominal forms. Vocatives are understood as words or phrases denoting the addressee, used for direct address, standing outside the main body of the clause and being separated from it by intonation. Vocatives are different from verbal and pronominal forms of address which are incorporated into the main body of the clause (Szarkowska 2007b). Bruti \& Perego $(2010: 64 ; 2008: 12)$ propose the following categorisation of the functions of vocatives: an "identifying" function, that either selects an addressee, or - especially if the vocative is repeated - as a reminder within a conversation, lending it a personal tone; and an "expressive" function, when it is not necessary to select an addressee but the speaker's attitude towards the addressee is specified.

I would like to focus on pronominal forms of address, that is on translation of the pronoun you, "creating, maintaining or reinforcing the social bond between collocutors" (Bruti/Perego 2008:12) as it was fraught with consequences and determined the reception of the main protagonist in the German and Polish translation.

As is well known, English constitutes an unusual case in address if compared to other languages in Europe (Helmbrecht 2003, 2005). English, in fact, is characterized by a reduced pronominal paradigm which does not distinguish between a formal and an 
informal address pronoun. Consequently, in this language intimacy and deference cannot be conveyed through a binary address system.

There are two social parameters that seem to be of particular significance in regard to politeness. One involves the relative social rank, power and prestige of the individual members within the society, the other involves the social distance, i.e. the degree of intimacy and familiarity relative to one another. The relative social rank of an individual is "regulated by sociolinguistic and contextual parameters like gender, social class, status, nature of the relationship between the parties and type of encounter" (Formentelli 2009:183). The parameter of relative social distance describes the fact that people who are close relatives or friends or who belong to the same peer groups etc., are usually closer to each other than unrelated people who do not know each other on an every-day basis. It is obvious that these parameters and values play a role as conceptual categories and determine the choice of linguistic means for polite address (Helmbrecht 2003:193193).

\section{Discussion of selected data: The main protagonist and the pronoun you}

The American Gregory House was baptized by the Frankfurter Allgemeine Zeitung as the "miesepetrigste[n] Mediziner der Fernsehgeschichte", that is as the grumpiest doctor in the history of television ". Critics have described the character as "moody", "bitter", "antagonistic", "misanthropic"3, "grumpy", "maverick"4 and a "curmudgeon"5. The Global Language Monitor chose the word "curmudgeon" as the best way to describe the character ${ }^{6}$.

He lacks sympathy for his patients, he is lazy, authoritative, unmotivated, implacable, addicted to Vicodin. He refuses to wear the standard white lab coat to avoid patients recognizing him as a doctor, avoids the patients as well as his clinic duty and says that "everybody lies". He is a genius who does not mince his words and therefore frequently ends up in court.

On the other hand, the German dubbed House is obsequious. Representatives of the law, such as the Court and police officers, as well as patients he addresses - by the book - using the formal Sie. In the same way he addresses his team of diagnosticians being their superior, although in the German language the convention of using the formal address pronoun would require it solely in the case of official conversations, clinic duty or duty in the ward being a notion of distance, authority, and hierarchy. Using the polite form Sie addressing his colleague and hospital administrator, Dr. Lisa Cuddy, is also unnecessary. Helmbrecht convinces in his politeness distinction in personal pronouns

\footnotetext{
${ }^{1}$ Frankfurter Allgemeine Zeitung, 9.05.2006, Nr. 107:42.

${ }^{2} \mathrm{http} / / /$ www.sfgate.com/cgi-bin/article/article?f=/c/a/2004/11/15/DDGSL9QOII1.DTL (Retrieved 2011-07-13).

${ }^{3} \mathrm{http}: / /$ www.popmatters.com/pm/tv/reviews/48955/house/ (Retrieved 2011-07-13).

${ }^{4} \mathrm{http} / / /$ blogs.thestage.co.uk/tvtoday/2007/11/top-5-grumpy-tv-doctors/. (Retrieved 2011-07-13).

${ }^{5} \mathrm{http}: / / \mathrm{www}$. salon.com/mwt/feature/2007/05/29/hugh_laurie/. (Retrieved 2011-07-13).

${ }^{6} \mathrm{http}: / /$ www.languagemonitor.com/?page_id=20. (Retrieved 2011-07-13).
} 
that "[t]he polite pronoun Sie is the default form of address among German adults who are not in a close social relation to each other. If they are relatives, married, close friends, professional colleagues, or university students, they are very likely to use the familiar $d u$ to address each other" (Helmbrecht 2005: 186).

As stated above, the English is characterized by a reduced pronominal paradigm which does not distinguish between a formal and an informal address pronoun. Consequently, we must assume that according to the social convention, the patients and hospital staff address the main character using polite forms:

\begin{tabular}{|c|c|c|}
\hline you & $\begin{array}{c}\text { Sie [second-person polite } \\
\text { pronoun] }\end{array}$ & pan [Sir] \\
\hline
\end{tabular}

Again we must assume that although the convention would require of House to answer symmetrically, the main protagonist answers asymmetrically, showing an impolite manner to everyone. Such a lack of distinction between a formal and an informal address pronoun makes it especially difficult in translation to render. The lack of symmetry is not visible in the German dubbing, though it can be found in the Polish AVT:

\begin{tabular}{|c|c|c|}
\hline you & Sie & $\begin{array}{c}\text { ty [second-person familiar } \\
\text { pronoun] }\end{array}$ \\
\hline
\end{tabular}

Szarkowska (2007a: 527) suggests that the habit of familiar addressing might be sometimes regarded as too direct and too curt, and this is the most likely reason why the "correct" address forms in the German dubbing are being placed in the mouth of most direct and most curt protagonist. In effect, the reader of the German book as well as the German viewer does not perceive the mentioned asymmetry in the behaviour of Gregory House.

An example illustrating an asymmetric address can be the following dialogue, where a male patient addresses the doctor using a polite form Sie, the doctor however replies (in Polish) as to a child using familiar verbal forms where the pronoun is superfluous:

\begin{tabular}{|l|l|l|}
\hline - My pants tell you I have & - Sie haben an meinen & - No i spodnie. \\
diabetes? & Hosen Diabetes erkannt? & - Mówią panu, że mam \\
- No, they tell me you're an & - Nein, aber dass Sie blöd & cukrzycę? \\
idiot. (...) Based on the two & sind. (...)die beiden & - Że jesteś głupkiem. (...) \\
napkins in your right & Kuchenservietten in Ihrer & a chusteczki w kieszeni \\
pocket, I'm willing to bet & Hosentaschen sagen mir, & wskazują, ile zjadteś \\
it's not your first donut of & dass das heute nicht Ihr & pączków. \\
the day. & erster Donut. (p. 47/episode & \\
& $9)$
\end{tabular}

House [to a female patient]:

You have a parasite.

Sie haben einen Parasiten. Masz pasożyta.

(p. 28/episode 4) 
In very rare cases the AVT translators decided to leave the formal and respectful form Pani [Madam] as in the following dialogue with an older female patient:

\begin{tabular}{|l|l|l|}
\hline $\begin{array}{l}\text { - But I am going to admit } \\
\text { you to the hospital for } \\
\text { tests. }\end{array}$ & $\begin{array}{l}\text { - Ich nehme Sie auf Tests. } \\
\text { (p. 44/episode 8) }\end{array}$ & $\begin{array}{l}\text { - Ale przyjmę pania na } \\
\text { badania. }\end{array}$ \\
\hline
\end{tabular}

In the closing scene however the translators went back to the form typical of the main character:

Do you think I would have given you this if it would stop you from flirting with me? [...] Doomed to feeling good for the rest of your life.
Sie sind verdammt, sich bis an $I h r$ Lebensende wohl zu fühlen. (p. 44/episode 8)
Myślisz, że dałbym ci lek, przez który przestaniesz ze mną flirtować? [...] Jesteś skazana na dobre samopoczucie do końca życia.

The same inconsistency in the triad: English - German - Polish can be found in House addressing the subordinates, which the protagonist always addresses with familiar forms. The familiarity is maintained in the Polish AVT, in the German dubbing however again omitted.

Chase: Genetic tests take forever. You can't just keep testing him for every inherited condition you think it might be.

House: Well, not me. (...) But you guys can.
Eine Gendiagnostik dauert ewig. Wir können doch nicht weiter auf jede Erbkrankheit testen, die Sie für möglich halten.

House: Ich nicht. (...) Aber House: Ja nie, ale wy tak. Sie können das. (p. 184/episode 53)
Diagnostyka genów trwa całą wieczność. Nie możemy zbadać każdej choroby dziedzicznej, którą podejrzewasz.
[House to his assistant, Dr. Chase]

You hate nuns. You can't hate someone if you don't know them.
Sie hassen Nonnen, Sie $\mid$ Nie możesz nienawidzić können keinen hassen, den kogoś, kogo nie znasz.

Sie nicht kennen. (p. 32/episode 5)
[House to his assistant, Dr. Cameron] Why are you here? To buy me a pony?

\begin{tabular}{|l|l|}
\hline Wieso sind Sie hier? & Po co przyszłaś? \\
Bekomme ich ein Pony? & Podarować mi kucyka?
\end{tabular}

House: Because... I'm your boss.

Cameron: A rational reason. Or at least admit that you don't have one.

- Weil ich Ihr Boss bin. - Ein rationaler Grund. Oder geben Sie wenigstens $\mathrm{zu}$, dass Sie keinen haben. (p. 216/episode 62)
- Bo jestem twoim szefem. - Sensownego uzasadnienia. Powiedz chociaż, że nie ma uzasadnienia. 
Typical of the main character is also the intimate way of addressing people performing professions of public trust, e.g. judges and police officers. Disrespectful attitude towards such people noticeable at the first glance by the English and Polish recipient is again undetectable in the German dubbing:

\begin{tabular}{|l|l|l|}
\hline [Judge] Dr House! Now! & - Dr House! Legen Sie auf. & Prosze natychmiast \\
[House] Does your voice & Sofort! & \multicolumn{2}{|c|}{ wytaczyć telefon! } \\
always get that high and & - Ist Ihre Stimme immer so & Zawsze masz taki \\
annoying when you're & nervig schrill, wenn Sie & skrzekliwy głos, kiedy się \\
angry? & $\begin{array}{l}\text { böse werden? } \\
\text { 197/episode 57) }\end{array}$ & złościsz? \\
\hline
\end{tabular}

When a Police officer, Michael Tritter, decides to struggle against House's disrespectful manner of handling patients, promises to take up legal action against the doctor and starts treating him with due lack of respect, owing to the wrong global translation strategy (Tomaszkiewicz 2004: 95; 2006: 103) the German recipient will unfortunately not discover the disrespect. As stated above, the display of disrespect in English is not based on using a socially inappropriate form of address, however if the main character were as polite as the German dubbing suggests, he probably would have addressed a policeman as e.g. "officer" and the judge as e.g. "Your Honour". Therefore using the formal address in German takes the edge out of the offensive remarks to some (minor) degree while using informal address aggravates the offence in the Polish voice-over.

\begin{tabular}{|c|c|c|}
\hline $\begin{array}{l}\text { And you're smart, and } \\
\text { you're funny but you are } \\
\text { bitter. And you're lonely, } \\
\text { so you treat everyone } \\
\text { around like they're idiots } \\
\text { and you get away with it } \\
\text { because of your cane. (...) } \\
\text { Last nurse you made fun of, } \\
\text { she probably slipped some } \\
\text { crap into your coffee. }\end{array}$ & $\begin{array}{l}\text { Sie sind clever und dazu } \\
\text { noch witzig, aber auch } \\
\text { verbittert und einsam. Und } \\
\text { deswegen behandeln Sie } \\
\text { alle wie Idioten und } \\
\text { kommen damit durch. } \\
\text { Dank Ihres Stocks. (...) } \\
\text { Die letzte Schwester, die } \\
\text { Sie verspottet haben, hat } \\
\text { Ihnen bestimmt etwas unter } \\
\text { den Kaffee gemischt. (p. } \\
\text { 180, episode 51). }\end{array}$ & $\begin{array}{l}\text { Jesteś inteligentny } \mathrm{i} \\
\text { dowcipny, ale też } \\
\text { zgorzkniały i samotny i } \\
\text { dlatego traktujesz } \\
\text { wszystkich jak idiotów i } \\
\text { zawsze uchodzi ci to } \\
\text { płazem. Bo chodzisz o } \\
\text { lasce. (...) Ta pielęgniarka, } \\
\text { którą zmieszałeś z błotem, } \\
\text { już pewnie dosypała ci } \\
\text { jakieś gówno do kawy. }\end{array}$ \\
\hline
\end{tabular}

Typical for the TV series is the constant bantering of two main characters, Dr. Gregory House and his superior, Dr. Lisa Cuddy, who know each other from the times from before the work in the Plainsboro Hospital:

\begin{tabular}{|l|l|l|}
\hline $\begin{array}{l}\text { [Cuddy]: When I hired you, } \\
\text { I knew you were insane. }\end{array}$ & $\begin{array}{l}\text { Ich habe Sie eingestellt, } \\
\text { obwohl ich wusste, dass Sie } \\
\text { irre sind. (p. 46/episode 9) }\end{array}$ & $\begin{array}{l}\text { Zdecydowałam się ciebie } \\
\text { zatrudnić, } \\
\text { wiedziałam, że jesteś } \\
\text { wariat. }\end{array}$ \\
\hline
\end{tabular}




\section{[Cuddy to House]: Are you Sind Sie etwa high? (p. $\quad$ Naćpateś się?} high? 95/episode 24)

The polite forms are surprising regarding the fact that the protagonists know each other since the university times, that House is Cuddy's subordinate, and considering the sexual allusions. The rejection of the personal $d u$ form makes the irony impossible to spot, when dr. House ironically comments on various things concerning doctor Cuddy's way of being, addressing her as using the academic title + surname, as in the following example of mocked politeness:

Good morning, doctor Cuddy, a stunning costume.
Guten Morgen Dr. Cuddy. Bezauberndes Kostüm. (s. 36/episode 6)
Dzień dobry, pani doktor, śliczny strój.

In Cambridge Grammar of Spoken and Written English (2007: 110) we read that "the title + surname is increasingly relegated to marking a more distant and respectful relationship towards the acquaintance". By choosing the right global strategy in the Polish AVT, the Polish translators could allow for the irony using the address form pani doctor (literally: "ms. doctor"). In such cases, mocked politeness is undetectable in the German dubbing.

\section{Conclusion}

The global translation strategy has made it possible for the Polish doctor House to be closer to its American counterpart. In my perspective, this is exactly what the character from Die kleine House-Apotheke should be like, bearing in mind, that the protagonist should be well known to his fan and avid TV series viewer. Dr. House's medical students are taught that when they hear hoofbeats, they should think horses, not zebras, but House's unique way of being has proven otherwise. Analogically, the pronoun you in the given context has turned out to be a 'horse' in the German dubbing, but was detected as a 'zebra' in the Polish voice-over. Therefore the strategy chosen by Polish AVT translator should be the leading one for translating the book Die kleine House-Apotheke.

In the Polish language the decisive factor is the degree of intimacy between the interlocutors, their age and social rank. The Polish doctor House is closer to its American counterpart. The Polish AVT translators had recognised correctly the main protagonist's attitude, his way of being, his constant provocation. Had this not been so, it would have created a significant obstacle for the translation of the book and would affect the reception of the main protagonist by fans and viewers in Poland. The American House disregards the conventionalities in every aspect and so should have the German dubbed House. "Im Deutschen lügt man, wenn man höflich ist" or literally: "In German you lie when you are polite" recalls the words of Baccalaureus in Faust II Eugeniusz Tomiczek (1991: 15) in one of his papers. Unfortunately this general remark can be applied to our needs, as it must be recognised that when the German dubbed House is polite, he (or rather the translators) lie, making him polite. 
Szarkowska (2006: 215) convinces that a translator should possess the so-called communicative competence, that is not only know the repertoire of respective words, but know, in what circumstances they might be used. In my opinion a translator must also know, how to convey the disregarding of conventionalities according to the relations between the interlocutors.

\section{References}

Barnett, Barbara. 2010. Chasing Zebras: The Unofficial Guide to House, M.D. ECW Press: Toronto.

Bruti, Silvia \& Perego, Elisa. 2010. "The audiovisual genre and translation of vocatives in interlingual subtitles." In Ł. Bogucki \& K. Kredens (eds.), Perspectives on Audiovisual Translation (61-75). Frankfurt am Main: Peter Lang.

Bruti, Silvia \& Perego, Elisa,. 2008. "Vocatives in Subtitles: a Survey across Genres." In Ecolingua. The Role of E-corpora in Translation and Language Learning (11-51). Triest: EUT - Edizioni Università di Trieste.

Díaz Cintas, Jorge \& Pilar Orero. 2005. "Voice-over". In K. Brown (ed.), Elsevier Encyclopedia of Language and Linguistics (477-480). Oxford: Elsevier.

Formentelli, Maicol. 2009. "Address Strategies in British Academic Setting". Pragmatics, 19:2, 179-196.

Helmbrecht, Johannes. 2003. "Politeness distinctions in second person pronouns." In F. Lenz (ed.), Deictic conceptualization of space, time and person (185-203). Amsterdam: Benjamins.

Helmbrecht, Johannes. 2005. "Politeness Distinctions in Pronouns." In M. Haspelmath, M. S. Dryer, D. Gil \& B. Comrie (eds.), The World Atlas of Language Structures (186-190). Oxford: Oxford University Press.

Huddlestone, Rodney \& Pullum, Geoffrey K.. 2002. The Cambridge Grammar of the English Language. Cambridge: Cambridge University Press.

Jackman, Ian \& Laurie, Hugh. 2010. House, M.D.: The Official Guide to the Hit Medical Drama. New York: Harpercollins.

Levinson, Stephen C.. 1983. Pragmatics, Cambridge: Cambridge University Press.

Reufsteck, Michael \& Stöckle, Jochen. 2008. Die kleine House-Apotheke. Ein Beipackzettel zur Kultserie. Egmont: Köln.

Shuttleworth, Mark \& Cowie, Moira (eds.). 1997. Dictionary of Translation Studies. Manchester: St. Jerome Publishing.

Szarkowska Agnieszka. 2007a. "Mów mi you, czyli językowy obraz Anglików i Polaków w Anglii, w Polsce i w przekładzie". In A. Szczęsny \& K. Hejwowski (eds.), Językowy obraz świata $w$ oryginale i przektadzie (523-534). Siedlce: Instytut Lingwistyki Stosowanej Uniwersytetu Warszawskiego.

Szarkowska Agnieszka. 2007b. "Why are Some Forms of Address not omitted in Subtitling? A Study Based on Three Selected Polish Soap Operas Broadcast on TV Polonia. Intermedia Conference, Łódź, Poland, 13-14 April 2007. 
Szarkowska Agnieszka. 2006. "Formy adresatywne w przekładzie z języka angielskiego na polski”. In L. Zieliński \& M. Pławski (eds.), Rocznik przekładoznawczy. Studia nad teoria, praktyka i dydaktyka przekładu (211-221). Toruń: Wydawnictwo UMK.

Szarkowska Agnieszka. 2009. "The Audiovisual Landscape in Poland at the Dawn of the 21 st Century”. In A. Goldstein \& B. Golubowić (eds.), Foreign Language Movies Dubbing vs. Subtitling (186-201). Hamburg: Verlag Dr. Kovač.

Tomaszkiewicz Teresa. 2006. Przekład audiowizualny. Warszawa: Wydawnictwo Naukowe PWN.

Tomaszkiewicz Teresa. 2004. Terminologia ttumaczenia. Poznań: Wydawnictwo Naukowe UAM.

Tomiczek, Eugeniusz. 1991. “Z badań nad istotą grzeczności językowej”. In J. Anusiewicz \& M. Marcjanik (eds.), Język a kultura, 6, 15-25.

\begin{abstract}
About the Author
Anna Urban is employed at the Department of German Applied Linguistics at the Institute of Applied Linguistics of Adam Mickiewicz University, Poznań, Poland. Her research interests focus on phraseology, translation, the Poznan dialect. In 2009 she published a study on the functions of phrasemes in the feature articles of Frankfurter Allgemeine Zeitung. Since 2003 she has been working as a translator of German and English books for young adults
\end{abstract}

